\begin{tabular}{|c|c|c|}
\hline Beitr. Ent. & Keltern & ISSN 0005-805X \\
\hline $\mathbf{5 6}(2006) 2$ & S. 405 & 15.12 .2006 \\
\hline
\end{tabular}

\title{
Zur Arthropodenfauna von Brandenburg - Ergebnisse der Untersuchungen 1995 - 1997 in Lebus / Oder ${ }^{1}$
}

\section{Dieter BarndT}

\begin{abstract}
Zusammenfassung
Das Gebiet um Lebus zeichnet sich, neben seinem faunistischen Wert durch viele Erst- und Wiederfunde, vor allem durch das Vorkommen zahlreicher xerothermobionter Arten aus. Einige von ihnen erreichen im Odergebiet die Nord- oder Westgrenze ihres Verbreitungsareals. Im Untersuchungszeitraum wurden im NSG Oderberge und Umgebung auf 20 Untersuchungsflächen 1198 Arthropodenarten festgestellt. Die Gefährdung ausgewählter Arten und Lebensräume wurde angegeben. Das synbioloigsche Verhalten der Meloidenarten zu der artenreichen Hymenopterenfauna, die durch die Habitatsstruktur der z. T. vegetationsarmen lößhaltigen Oderhänge bedingt ist, wurde dargestellt und charakteristische Artenkombinationen ausgewählter Lebensräume beispielhaft genannt. Der Käferbestand des Gebietes ist seit 1930 nahezu unverändert. Es wurde eine naturschutzfachliche Bewertung der Lebensräume mitgeteilt. Die subkontinentalen Steppenrasen der Oderhänge und das unverbaute Oderufer konnten als wertvollste Gebiete ermittelt und Pflegehinweise zu deren Schutz gegeben werden.
\end{abstract}

\section{Summary}

The area around Lebus is remarkable for the occurrence of numerous xerothermophile species, as well as for its faunistic value in providing many first records and records of rediscovered species. Some of these reach the northern or western edge of their range in the Oder Region. During the research period 1198 species of arthropods were recorded on 20 sampling areas in the Oderberge Nature Reserve. The degree of endangerment of selected species and types of habitat is indicated. The synbiological behaviour of Meloidae species with respect to the species-rich fauna of Hymenoptera (determined by the habitat structure, partly sparse vegetation, and loess content of the soil on the slopes of the Oder Valley) is described and characteristic combinations of species presented in exemplary fashion for selected habitats. The inventory of beetles for the area is nearly unaltered since 1930. An evaluation of the habitats for the purposes of nature conservation is presented. The subcontinental steppe-grasslands of the Oder Valley slopes and the sections of banks of the Oder without dams are identified as areas of the highest value. Recommendations are made for methods of management which will help protect them.

\section{Key words}

Odergebiet, Steppenrasen, Carabidae, Staphylinidae, Araneae, Bewertung, Naturschutz

Anschrift des Verfassers: Prof. Dr. Dieter Barndt, Bahnhofstrasse 40 d, D - 12207 Berlin e-mail: dr.barndt@t-online.de

\footnotetext{
${ }^{1}$ Kurzfassung des Vortrags, Einzelheiten siehe : / Summary of the lecture, for details see:

BARNDT, D. 2005: Beitrag zur Arthropodenfauna der Oderhänge und der Oderaue von Lebus - Faunenanalyse und Bewertung (Coleoptera, Heteroptera, Hymenoptera, Saltatoria, Araneae, Opiliones u. a.). - 4. Ergebnisbericht der entomologischen Untersuchungen in Brandenburg 1995-2002. - Märkische Entomologische Nachrichten 7 (1): 1-52.
} 